\title{
Antitrust Arbitration and Illinois Brick ${ }^{1}$
}

\author{
Mark A. Lemley* \& Christopher R. Leslie ${ }^{* *}$
}

ABSTRACT: For nearly 40 years, since the Supreme Court decision in Illinois Brick, federal antitrust law has prevented indirect purchasers from complaining of overcharges caused by antitrust violations. The Court reasoned that direct purchasers are the best and most motivated antitrust plaintiffs. But in its 2013 Italian Colors decision, the Court made it extremely difficult for direct purchasers to bring an antitrust claim in federal court. In doing so, it undermined the policy rationale for Illinois Brick, paving the way for courts to reconsider the ban on antitrust enforcement by indirect purchasers.

I. INTRODUCTION

II. ILLINOIS BRICK: ITS HOLDING AND RATIONALE 103

III. ANTITRUST ARBITRATION AT THE DAWN OF ILLINOIS BRICK 106

IV. The Evolution OF ANTITRUst ARbitration IN THE POST-ILLINOIS BRICK ERA 108

V. ITALIAN COLORS UNDERMINES THE RATIONALE OF ILLINOIS BRICK 114

VI. IMPLICATIONS FOR ANTITRUST LAW

1 (c) 2015 Mark A. Lemley \& Christopher R. Leslie.

* William H. Neukom Professor of Law, Stanford Law School; Partner, Durie Tangri LLP.

** Chancellor's Professor of Law, University of California Irvine School of Law. We thank Josh Davis, Christopher Drahozal, Jordan Elias, Rose Hagan, Scott Hemphill, Herb Hovenkamp, Doug Melamed, Barak Orbach, Tony Reese, and participants at a symposium at the University of Iowa College of Law for comments on a prior draft. 


\section{INTRODUCTION}

The proper role of private enforcement in antitrust law has long been debated. One of the most significant judicial reforms of antitrust law associated with the Chicago School was the Supreme Court's decision to limit standing to direct purchasers in Illinois Brick Company v. State of Illinois. ${ }^{2}$ Although that decision has proven controversial, the Illinois Brick doctrine has endured as a principle of federal antitrust law for nearly 40 years.

Whatever the merits of the Illinois Brick decision in 1977, subsequent developments have undermined its rationale. In particular, the Supreme Court's 2013 decision in American Express v. Italian Colors ${ }^{3}$ undercuts the fundamental premises of the Illinois Brick doctrine. The Illinois Brick majority assumed that direct purchasers were the most motivated and the best situated to enforce antitrust laws that resulted in supracompetitive prices. But Italian Colors makes it very difficult for direct purchasers to enforce antitrust laws in a wide variety of circumstances, because the decision allows potential antitrust defendants to use arbitration clauses in standard-form contracts to ban antitrust class actions and require individual arbitration of antitrust disputes. The result is to deprive overcharged direct purchasers of the tools antitrust law offers for effective enforcement - class action status, a lengthy statute of limitations, treble damages, and, if successful, attorneys' fees. ${ }^{4}$ Without effective opportunities for enforcement by direct purchasers, the rationale for excluding indirect purchasers from bringing antitrust claims collapses.

Antitrust law is common law and is often based on policy arguments. The decision in Illinois Brick is no exception. The Court based its reasoning on its assessment of the ability of direct purchasers to enforce antitrust laws effectively. After Italian Colors, that is no longer the case. Old doctrines must give way in light of legal developments (including later judicial opinions) that change the underlying environments and undermine the original policy arguments upon which the old common law is based. By eliminating most antitrust enforcement by direct purchasers, Italian Colors has paved the way for reconsideration of Illinois Brick. ${ }^{5}$

2. Ill. Brick Co. v. Illinois, 431 U.S. 720,737 (1977).

3. Am. Express Co. v. Italian Colors Rest., 133 S. Ct. 2304 (2013).

4. $\quad 15$ U.S.C. $\$ 15 a(2013)$.

5. It is possible that the Court didn't actually mean what it said, and that it just wanted to reduce or eliminate private enforcement altogether, as some have suggested doing. See, e.g., William Breit \& Kenneth G. Elzinga, Antitrust Enforcement and Economic Efficiency: The Uneasy Case for Treble Damages, 17 J.L. \& Econ. 329 (1974). If you do not think there is a role for private enforcement, you might view Italian Colors as a further step towards its elimination and therefore a good thing, no matter how disingenuous. We start from the premise that at least some private antitrust enforcement is desirable. 


\section{ILLINOIS BRICK: ITS HOLDING AND RATIONALE}

Courts have long been suspicious of competitors as antitrust plaintiffs,${ }^{6}$ in part because competitor interests do not necessarily align well with consumer interests. For example, competitors might object to conduct that benefits consumers, such as aggressive price competition. ${ }^{7}$ Beginning in the 1970 s, courts began creating limits on competitor standing in an effort to tackle that disconnect. ${ }^{8}$

Consumers, by contrast, are, in some sense, the perfect antitrust plaintiffs. They are the intended beneficiaries of the competitive markets that antitrust policy seeks to encourage; consumers are injured by cartels and other anticompetitive conduct, but benefit from aggressive competition on the merits. Accordingly, courts have long permitted purchasers to sue to recover overcharges that result from cartels, ${ }^{9}$ though some courts have (incorrectly) questioned customers' standing to enforce the antitrust laws. ${ }^{10}$

In Illinois Brick, the plaintiffs were state and local governments who sought recovery for overcharges that resulted from a cartel that fixed the prices of concrete blocks. But the governments did not buy the blocks directly from the defendants. Rather, construction contractors bought the blocks and used them to build buildings, which the governments later bought. ${ }^{11}$ The governments were indirect purchasers; their injury came from the fact that the contractors, who paid an artificially high price, passed that higher price on to them. ${ }^{12}$

The Supreme Court held that indirect purchasers could not recover the overcharges that direct purchasers passed on to them. ${ }^{13}$ Illinois Brick was decided on two basic policy considerations. First, the Court concluded that because antitrust law permits direct purchasers to recover the entirety of the overcharge they faced, without having to deduct price increases they passed on to their own customers, ${ }^{14}$ allowing indirect purchasers to also sue for the same antitrust

6. See, e.g., Brown Shoe Co. v. United States, 370 U.S. 294, 320 (1962) (noting that the antitrust laws were passed for "the protection of competition, not competitors").

7. See, e.g., Brunswick Corp. v. Pueblo Bowl-O-Mat, Inc., 429 U.S. 477 (1977).

8. See, e.g., Cargill, Inc. v. Monfort of Colo., Inc., 479 U.S. 104, 110-13 (1986); Associated Gen. Contractors of Cal., Inc. v. Cal. State Council of Carpenters, 459 U.S. 519, 529-33, 538-46 (1983); Blue Shield of Va. v. McCready, 457 U.S. 465, 473-78 (1982); Brunswick Corp., 429 U.S. at 489. .

9. Hanover Shoe, Inc. v. United Shoe Mach. Corp., 392 U.S. 481, 487-88 (1968).

10. See, e.g., Ritz Camera \& Image, L.L.C. v. SanDisk Corp., 700 F.3d 503, 508 (Fed. Cir. 2012) (reaffirming the ability of direct purchasers to bring antitrust cases over claims that they lacked standing); In re DDAVP Direct Purchaser Antitrust Litig., 585 F.3d 677, 688 (2d Cir. 2009) (same). See generally Christopher R. Leslie, The Role of Consumers in Walker Process Litigation, 13 Sw. J.L. \& TRADE AMS. 281 (2007).

11. Ill. Brick Co. v. Illinois, 431 U.S. 720, 726-29 (1977).

12. Id. at 727 .

13. Id. at $728-29,736$.

14. The Supreme Court rejected the so-called pass-on defense in Hanover Shoe, Inc. v. United Shoe Machinery Corp., 392 U.S. 481 (1968). 
violation would create a double recovery. ${ }^{15}$ The Court considered reversing the rule allowing direct purchasers to recover the entire overcharge without deduction, but rejected that argument because of its second conclusion: that direct purchasers were the best positioned to enforce antitrust law. ${ }^{16}$ The Court interpreted its prior decision to reject a passing-on defense to antitrust claims to support the proposition "that the antitrust laws will be more effectively enforced by concentrating the full recovery for the overcharge in the direct purchasers rather than by allowing every plaintiff potentially affected by the overcharge to sue only for the amount it could show was absorbed by it." ${ }^{17}$ Further, the majority concluded that denying standing to indirect purchasers was more consistent with "the legislative purpose in creating a group of "private attorneys general' to enforce the antitrust laws" because direct purchasers could sue for "the full extent of the overcharge paid by them [without having] to apportion the overcharge among all that may have absorbed a part of it." 18 The Court also felt that direct purchase overcharges were easier to measure than pass-throughs, particularly if courts had to allocate the injury between the direct and indirect purchasers. ${ }^{19}$

The dissent worried that indirect purchasers would be short-changed. ${ }^{20}$ The majority responded that allowing direct purchasers to recover the entirety of the overcharge would not only be simpler to calculate, but would also promote more vigorous antitrust enforcement by centralizing the incentive to sue in one party who could recover all the losses. ${ }^{21}$ In short, Illinois Brick reflected an economic conclusion that one, but only one, overcharged purchaser in the downstream chain should be entitled to sue, and that for various reasons the simplest and most effective solution was for the direct purchaser to be that one purchaser-plaintiff. ${ }^{22}$

The Illinois Brick ruling proved controversial. Some commentators decried it: ${ }^{23}$ others defended it. ${ }^{24}$ The leading antitrust treatise expresses doubt about the wisdom of the doctrine:

15. Ill. Brick Co., 431 U.S. at 730.

16. Id. at $745-47$.

17. Id. at 735 .

18. Id. at 746 .

19. Id. at $741-43$.

20. Id. at 748 (Brennan, J., dissenting).

21. Id. at $745-46$.

22. Exceptions exist, such as cost-plus contracts. See id. at 736 ("In [a cost-plus contract] situation, the [direct] purchaser is insulated from any decrease in its sales as a result of attempting to pass on the overcharge, because its customer is committed to buying a fixed quantity regardless of price."). See also Donald I. Baker, Revisiting History-What Have We Learned About Private Antitrust Enforcement That We Would Recommend to Others?, 16 LOY. CONSUMER L. REV. 379, 391 (2004) ("Indirect purchasers should have standing to sue, but under procedural rules that encourage or even mandate consolidation of their claims with those of direct purchasers." (citing Donald I. Baker, Federalism and Futility: Hitting the Potholes on the Illinois Brick Road, ANTITRUST MAG., Fall 2002, at 14 [hereinafter Baker, Federalism and Futility])). But see Kansas v. UtiliCorp United, Inc., 497 U.S. 199, 217-18 (1990) (rejecting application of cost-plus exception).

23. See, e.g., Edward D. Cavanagh, Illinois Brick: A Look Back and a Look Ahead, 17 LoY. Consumer L. Rev. 1, 18 (2004); Andrew I. Gavil, Thinking Outside the Illinois Brick Box: A Proposal 
The obvious difficulty with denying damages for consumers buying from an intermediary is that they are injured, often more than the intermediary, who may also be injured but for whom recovery of the entire overcharge is typically a windfall. Thus the indirect purchaser rule greatly overcompensates intermediaries and greatly undercompensate[s] consumers in the name of efficiency in the administration of the antitrust laws.

...

[Section 4] of the Clayton Act awards damages to the person who is "injured," and Illinois Brick frequently gives the award to the wrong person. ${ }^{25}$

Thirty-five states have rejected the doctrine, permitting antitrust enforcement by indirect purchasers under their state antitrust laws. ${ }^{26}$ As a result, judges and scholars have developed a sophisticated body of law and economic thought on the problem of computing downstream overcharges, though that law has developed primarily in state, rather than federal, antitrust cases. ${ }^{27}$

Furthermore, in the years that followed, the Court put substantial constraints on the ability of competitors to bring private antitrust suits. For example, the Court

for Reform, 76 ANTITRUST L.J. 167, 171 (2009); J. Thomas Prud'homme, Jr. \& Ellen S. Cooper, One More Challenge for the AMC: Repairing the Legacy of Illinois Brick, 40 U.S.F. L. REV. 675, 683-84 (2006); cf. Roger D. Blair \& Jeffrey L. Harrison, Reexamining the Role of Illinois Brick in Modern Antitrust Standing Analysis, 68 GEO. WASH. L. REV. 1, 3 (1999) (arguing that Illinois Brick should be retained but limited).

24. See, e.g., Barak D. Richman \& Christopher R. Murray, Rebuilding Illinois Brick: A Functionalist Approach to the Indirect Purchaser Rule, 81 S. CAL. L. REV. 69, 84 (2007); Gregory J. Werden \& Marius Schwartz, Illinois Brick and the Deterrence of Antitrust Violations-An Economic Analysis, 35 HASTINGS L.J. 629, 637-38 (1984).

25. 2A Phillip E. Areeda, Herbert Hovenkamp, Roger D. Blair \& Christine Piette

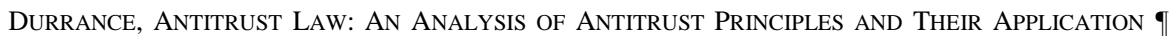
346k at 189, 197 (3d ed. 2007); see also HERBERT HovenKAMP, THE ANTITRUST ENTERPRisE: PRINCIPLE AND EXECUTION 74-76 (2005) (criticizing Illinois Brick); Herbert Hovenkamp, Commentary, The Indirect-Purchaser Rule and Cost-Plus Sales, 103 HARV. L. REv. 1717, 1717 (1990).

26. See ANTITRUST MODERNIZATION COMm'n, REPORT AND ReCOMMENDATIONS 269 (2007) [hereinafter AMC REPORT], available at http://govinfo.library.unt.edu/amc/report_ recommendation/amc_final_report.pdf. For a summary of approaches taken by states that have repealed Illinois Brick, see Gale Price, One Short of a Load: Why an Illinois Brick Repealer Will Increase Private Antitrust Enforcement in Montana, 74 MonT. L. REv. 399, 406-09 (2013). The Supreme Court held in California v. ARC America Corp., 490 U.S. 93 (1989), that those state laws were not preempted by the federal rule in Illinois Brick. For a discussion of states to repeal Illinois Brick, see, for example, Baker, Federalism and Futility, supra note 21, at 17-18; Ronald W. Davis, Indirect Purchaser Litigation: ARC America's Chickens Come Home to Roost on the Illinois Brick Wall, 65 ANTITRUST L.J. 375, 391-93 (1997); Matthew M. Duffy, Chipping Away at the Illinois Brick Wall: Expanding Exceptions to the Indirect Purchaser Rule, 87 Notre DAME L. Rev. 1709, 1710 (2012); William H. Page, The Limits of State Indirect Purchaser Suits: Class Certification in the Shadow of Illinois Brick, 67 ANTITRUST L.J. 1, 16 (1999).

27. AREEDA ET AL., supra note 24, at If 396 (discussing the computation of overcharges in indirect purchaser cases, and rejecting the claim that it is too difficult). 
developed a new doctrine, "antitrust injury," which created higher standing hurdles in antitrust than in other private law doctrines. ${ }^{28}$ Government enforcement has also declined substantially during the period since Illinois Brick. ${ }^{29}$ Barriers to competitor standing increase the importance of purchaser standing to bring antitrust claims. ${ }^{30}$

As a result of the Illinois Brick decision and the Court's antitrust injury cases, for nearly 40 years, enforcement of the Sherman Act has been the province of government agencies, some competitors, and purchasers - but only the first, direct purchaser. While direct purchasers are sometimes consumers, they are often corporate intermediaries. For example, the direct purchasers of Microsoft Windows are usually computer manufacturers, not the people who actually use the software. ${ }^{31}$ Similarly, the direct purchasers of pharmaceuticals are drugstores, not patients. ${ }^{32}$ As a result, in many cases, antitrust relies on corporate proxies to represent consumer interests.

Reliance on corporate proxies had the potential to work, at least at first. An early empirical study suggested that the central premise of the Court's logic- that direct purchasers would be well motivated to sue-was borne out in fact. ${ }^{33}$ But subsequent changes in antitrust doctrine and practice require reevaluation of the premise that direct purchasers can, and will, litigate antitrust claims, and that they can do so better than indirect purchasers.

\section{ANTITRUST ARBITRATION AT THE DAWN OF ILLINOIS BRICK}

Illinois Brick is a product of its time. The majority based its opinion on several assumptions and policy judgments that, even if true in 1977, were not static. Most significantly for our purposes, the Court penned Illinois Brick at a time

28. See, e.g., Cargill, Inc. v. Monfort of Colo., Inc., 479 U.S. 104, 110 (1986); Associated Gen. Contractors of Cal., Inc. v. Cal. State Council of Carpenters, 459 U.S. 519, 538 (1983); Blue Shield of Va. v. McCready, 457 U.S. 465, 476-77 (1982); Brunswick Corp. v. Pueblo Bowl-O-Mat, Inc., 429 U.S. 477, 489 (1977). But see Lexmark Int'l, Inc. v. Static Control Components, Inc., 134 S. Ct. 1377, 1387-88 (2014) (rejecting the antitrust standing test as too restrictive for false advertising cases).

29. See, e.g., Sam Peltzman, The Decline of Antitrust Enforcement, 19 Rev. Indus. Org. 49, 49 (2001).

30. Although awarding antitrust damages to competitors does not compensate consumer victims of antitrust violations, competitor-initiated antitrust litigation can reduce the expected profitability of antitrust violations and, thus, increase deterrence, which ultimately benefits consumers.

31. In re Microsoft Corp. Antitrust Litig., 127 F. Supp. 2d 702, 710 (D. Md. 2001), supplemented, No. MDL-1332, 2001 WL 137254 (D. Md. Feb. 15, 2001), aff'd sub nom. Kloth v. Microsoft Corp., 444 F.3d 312 (4th Cir. 2006) ('Plaintiffs' supra-competitive price claims arise, very simply, from the assertion that Microsoft obtained monopoly profits from its sales to OEMs, who passed on these illegal overcharges to plaintiffs. This is the Illinois Brick paradigm, and plaintiffs' claims for supra-competitive prices are barred."); see also Mark v. Microsoft Corp. (In re Microsoft Corp. Antitrust Litig.), 401 F. Supp. 2d 461, 463 (D. Md. 2005) (following Illinois Brick in decision to bar indirect purchasers from bringing state claims against Microsoft).

32. See In re Brand Name Prescription Drugs Antitrust Litig., 123 F.3d 599, 606-07 (7th Cir. 1997).

33. See Werden \& Schwartz, supra note 23, at 667. 
when pre-dispute agreements to arbitrate antitrust claims were not enforceable. The legal landscape regarding antitrust arbitration has changed considerably in the intervening years.

The federal government's validation of private arbitration began in 1925 when Congress enacted the Federal Arbitration Act ("FAA"). ${ }^{34}$ Section 2 of the FAA provides that if a commercial contract contains an agreement to settle controversies that arise from the contract through private arbitration, the promise to arbitrate "shall be valid, irrevocable, and enforceable, save upon such grounds as exist at law or in equity for the revocation of any contract." 35 The FAA instructed federal courts to enforce agreements between firms to settle their commercial disputes through binding arbitration instead of going to court.

Although Congress passed the FAA in $1925,{ }^{36}$ federal courts did not meaningfully address the issue of the arbitrability of antitrust claims until the 1960s. In 1968, the Second Circuit in American Safety Equipment Corp. v. J.P. Maguire \& Co. became the first court of appeals to hold that antitrust claims were not subject to arbitration. ${ }^{37}$ The Second Circuit articulated four rationales for concluding that the FAA did not apply to antitrust claims:

(1) deference to private arbitration agreements could lessen the plaintiffs' incentive to pursue antitrust actions, weakening the use of "private attorneys general" as a foundation of Sherman Act enforcement; (2) arbitration clauses often result from adhesion contracts, and Congress intended that these matters be heard in the courts; (3) arbitrators may be incompetent to comprehend complex antitrust issues; and (4) arbitrators may be biased business people unable to reach fair outcomes. ${ }^{38}$

The American Safety rationale proved persuasive across the circuits, as courts relied on American Safety to hold that antitrust claims were not subject to

34. 9 U.S.C. $\S \S 1-200$ (2013); Bellevue Drug Co. v. Caremarks PCS (In re Pharmacy Benefit Managers Antitrust Litig.), 700 F.3d 109, 116 (3d Cir. 2012) ("Congress enacted the FAA in 1925 to counteract "the traditional judicial hostility to the enforcement of arbitration agreements." (quoting Alexander v. Anthony Int'l, L.P., 341 F.3d 256, 263 (3d Cir. 2003))).

35. 9 U.S.C. $\$ 2$.

36. John R. Allison, Arbitration Agreements and Antitrust Claims: The Need for Enhanced Accommodation of Conflicting Public Policies, 64 N.C. L. REV. 219, 227 (1986).

37. Am. Safety Equip. Corp. v. J. P. Maguire \& Co., Inc., 391 F.2d 821, 827-28 (2d Cir. 1968); Donald I. Baker \& Mark R. Stabile, Arbitration of Antitrust Claims: Opportunities and Hazards for Corporate Counsel, 48 Bus. LAw 395, 402 (1993).

38. Steven R. Swanson, Antisuit Injunctions in Support of International Arbitration, 81 TuL. L. Rev. 395, 409 (2006); see also Nghiem v. NEC Elec., Inc., 25 F.3d 1437, 1441-42 (9th Cir. 1994) ("In American Safety, the Second Circuit held that antitrust claims cannot be arbitrated because of the public interest in enforcing antitrust laws, the potential bias and limited expertise of arbitrators, the complexity of antitrust law, and the procedural differences between trials and arbitrations." (citing Am. Safety Equip. Corp., 391 F.2d at 826-27)); Ramona L. Lampley, Is Arbitration Under Attack?: Exploring the Recent Judicial Skepticism of the Class Arbitration Waiver and Innovative Solutions to the Unsettled Legal Landscape, 18 CORNELl J.L. \& PUB. POL'Y 477, 518 (2009) (reciting the four rationales in another fashion). 
arbitration. ${ }^{39}$ In fact, every court of appeals that considered the issue uniformly followed American Safety and held that antitrust claims were inappropriate for arbitration. ${ }^{40}$

By 1977, the year that Illinois Brick was decided, the Supreme Court had neither addressed the issue of antitrust arbitration nor questioned the validity of American Safety and its progeny. Until the mid-1980s, the American Safety rule prohibiting arbitration of antitrust claims was well established, widespread, and not particularly controversial. Thus, at the time of the Illinois Brick decision, antitrust arbitration was not a possibility. Private antitrust claims were litigated, not shunted off to private arbitration panels pursuant to pre-agreed-upon arbitration clauses. The Illinois Brick Court assumed that direct purchasers had an unhampered ability to bring antitrust claims in federal court. That assumption would not survive the following decade.

\section{The EVolution of ANTITRUST ARBITRATION IN THE POST-ILLINOIS BRICK ERA}

The American Safety doctrine began to erode in the 1980s, as the Supreme Court interpreted the FAA as creating a heavy presumption in favor of arbitration for all claims. ${ }^{41}$ The Supreme Court began to dislodge the American Safety doctrine when it considered whether Sherman Act claims could be decided by international arbitration tribunals in other countries. In Mitsubishi Motors Corp. v. Soler Chrysler-Plymouth Inc., the Supreme Court considered whether the American Safety rule should apply to the international arbitration of antitrust claims. ${ }^{42}$

The Court began by noting that it was primarily concerned with whether an American court should allow private parties to an international transactionpursuant to an arbitration clause in their commercial contract- to submit an

39. See, e.g., Lake Commc'ns, Inc. v. ICC Corp., 738 F.2d 1473, 1479 (9th Cir. 1984); Lee v. Ply*Gem Indus., Inc., 593 F.2d 1266, 1274-75 (D.C. Cir. 1979); Applied Digital Tech., Inc. v. Cont'l Cas. Co., 576 F.2d 116, 117-19 (7th Cir. 1978); Cobb v. Lewis, 488 F.2d 41, 47 (5th Cir. 1974) ("[A]ntitrust claims are not appropriate subjects of arbitration."); Coenen v. R.W. Pressprich \& Co., Inc., 453 F.2d 1209, 1215-16 (2d Cir. 1972); Helfenbein v. Int'1 Indus., Inc., 438 F.2d 1068, 1070-71 (8th Cir. 1971); Power Replacements, Inc. v. Air Preheater Co., 426 F.2d 980, 983-84 (9th Cir. 1970); A. \& E. Plastik Pak Co. v. Monsanto Co., 396 F.2d 710, 715-16 (9th Cir. 1968); In re Aimcee Wholesale Corp., 237 N.E.2d 223, 224-27 (N.Y. 1968).

40. Mitsubishi Motors Corp. v. Soler Chrysler-Plymouth, Inc., 473 U.S. 614, 620-21 (1985).

41. See Moses H. Cone Mem'l Hosp. v. Mercury Constr. Corp., 460 U.S. 1, 24 (1983) ("[Q]uestions of arbitrability must be addressed with a healthy regard for the federal policy favoring arbitration."); id. at 24-25 (noting that "[t]he Arbitration Act establishes that, as a matter of federal law, any doubts concerning the scope of arbitrable issues should be resolved in favor of arbitration, whether the problem at hand is the construction of the contract language itself or an allegation of waiver, delay, or a like defense to arbitrability").

42. Mitsubishi Motors Corp., 473 U.S. at 632-35. 
antitrust dispute to an international tribunal instead of a federal district court. ${ }^{43}$ When analyzing the arbitrability of the antitrust claims at issue, the Mitsubishi Court emphasized the international context of the dispute, noting that

[C]oncerns of international comity, respect for the capacities of foreign and transnational tribunals, and sensitivity to the need of the international commercial system for predictability in the resolution of disputes require that we enforce the parties' agreement, even assuming that a contrary result would be forthcoming in a domestic context. ${ }^{44}$

In reaching its result, the Court critiqued each rationale that the Second Circuit used to render antitrust claims non-arbitrable in American Safety. ${ }^{45}$ The Supreme Court also rejected any "presumption against arbitration of statutory claims." ${ }^{" 66}$ The Court, however, did not explicitly overrule the American Safety rule. Instead, it distinguished American Safety as not involving international transactions and found "it unnecessary to assess the legitimacy of the American Safety doctrine as applied to agreements to arbitrate arising from domestic transactions." 47

Although the Mitsubishi Court explicitly declined to reverse American Safety and to apply its opinion to domestic antitrust claims, some lower courts nevertheless interpreted Mitsubishi as making all antitrust claims arbitrable. ${ }^{48}$ For

43. Id. at 624 ("We granted certiorari primarily to consider whether an American court should enforce an agreement to resolve antitrust claims by arbitration when that agreement arises from an international transaction.").

44. Id. at 629 .

45. The Mitsubishi Court noted:

At the outset, we confess to some skepticism of certain aspects of the American Safety doctrine.... The mere appearance of an antitrust dispute does not alone warrant invalidation of the selected forum on the undemonstrated assumption that the arbitration clause is tainted.... Next, potential complexity should not suffice to ward off arbitration.... [W] e also reject the proposition that an arbitration panel will pose too great a danger of innate hostility to the constraints on business conduct that antitrust law imposes.... We are left, then, with the core of the American Safety doctrine-the fundamental importance to American democratic capitalism of the regime of the antitrust laws. ... The importance of the private damages remedy, however, does not compel the conclusion that it may not be sought outside an American court.

Id. at 632-36.

46. Id. at 625 .

47. Id. at 629 .

48. In re Cotton Yarn Antitrust Litig., 505 F.3d 274, 282 (4th Cir. 2007) ("Although the Supreme Court has yet to directly consider the arbitrability of domestic antitrust claims, the Court's analysis of the question in Mitsubishi is equally applicable to domestic antitrust claims .... We therefore have no difficulty concluding that domestic antitrust claims, as a class, are suitable for arbitration."); DJ Mfg. Corp. v. Tex-Shield, Inc., 998 F. Supp. 140, 145 (D.P.R. 1998) ("Even though the Court did not address the issue of arbitrability of antitrust issues in the domestic arena, it seriously undermined the rationale espoused by the Second Circuit in American Safety regarding the propriety of arbitration of antitrust issues in general."); see also Baker \& Stabile, supra note 36, at 406 ("Although the Court's holding in Mitsubishi is limited to the international arena, its logic is not."). 
example, the Ninth Circuit treated the Mitsubishi "Court's meticulous step-by-step disembowelment of the American Safety doctrine" as "effectively overrul[ing] American Safety and its progeny." ${ }^{49}$ Other circuits followed suit and began to revisit their rules against allowing domestic antitrust claims to be arbitrated, ultimately holding that, despite the fact that Mitsubishi involved international arbitration, the opinion required that domestic antitrust lawsuits be subject to arbitration. $^{50}$

The combination of Congress making arbitration clauses enforceable and federal courts holding that antitrust claims were arbitrable led many potential antitrust defendants to engage in a two-pronged strategy to minimize or avoid antitrust liability. First, many businesses imposed arbitration agreements on their distributors and customers. ${ }^{51}$ Second, they structured their arbitration clauses to

49. Nghiem v. NEC Elec., Inc., 25 F.3d 1437, 1442 (9th Cir. 1994)

50. See, e.g., Seacoast Motors of Salisbury, Inc. v. DaimlerChrysler Motors Corp., 271 F.3d 6, 11 (1st Cir. 2001) (expressly rejecting American Safety in view of Mitsubishi); Kotam Elecs., Inc. v. JBL Consumer Prods., Inc., 93 F.3d 724, 728 (11th Cir. 1996) ("In light of Mitsubishi and its progeny... we hold that... arbitration agreements concerning domestic antitrust claims are enforceable.”); see also HCI Techs., Inc. v. Avaya, Inc., 446 F. Supp. 2d 518, 524 (E.D. Va. 2006) (“A review of subsequent case law reveals that while the grim reaper may not yet have found American Safety's address, he is certainly in the neighborhood."); Tex-Shield, Inc., 998 F. Supp. at 145 ("[W]e also hold that domestic antitrust disputes . . . are arbitrable.”); Hunt v. Up N. Plastics, Inc., 980 F. Supp. 1046, 1049-50 (D. Minn. 1997) (finding the same); Acquaire v. Can. Dry Bottling, 906 F. Supp. 819, 837 (E.D.N.Y. 1995) (finding the same); Syscomm Int'l Corp. v. Synoptics Commc'ns, Inc., 856 F. Supp. 135, 139 (E.D.N.Y. 1994) ("While American Safety has not been explicitly overruled, this Court believes that ... domestic antitrust claims are arbitrable.”); Hough v. Merrill Lynch, Pierce, Fenner \& Smith, Inc., 757 F. Supp. 283, 286 (S.D.N.Y. 1991) (“[T]he reasoning of Mitsubishi should apply with equal force to domestic claims."), aff'd, 946 F.2d 883 (2d Cir. 1991); W. Int'l Media Corp. v. Johnson, 754 F. Supp. 871, 873-74 (S.D. Fla. 1991) ("Although the Court supported its rejection of some of these concerns on grounds tied to the principles involved in international commercial transactions, the Court's reliance on arbitration principles and the legislative histories of antitrust provisions suggests that the result arrived at in Mitsubishi would be forthcoming in the domestic situation.").

51. See Homa v. Am. Express Co., 494 F. App'x 191, 197 (3d Cir. 2012) ("In the years since Congress adopted the FAA, clauses containing class-arbitration waivers have become ubiquitous in contracts involving products and services distributed or supplied on a mass basis, such as contracts providing for cell phone service, credit cards, and cable service.”); Jason W. Burge \& Lara K. Richards, A Compelling Case for Streamlining Venue of Actions to Enjoin Arbitration, 88 TUL. L. REV. 773, 774 (2014) ("Arbitration agreements have become 'ubiquitous in American society.' If you have signed a contract for a cell phone, bought stock through a brokerage account, or accepted new employment, chances are you have signed a contract with an arbitration clause."); Joshua T. Mandelbaum, Stuck in a Bind: Can the Arbitration Fairness Act Solve the Problems of Mandatory Binding Arbitration in the Consumer Context?, 94 IOWA L. REV. 1075, 1084 (2009) ("The benefits that accrue to businesses that utilize mandatory-binding-arbitration clauses in consumer contracts help explain why these clauses have become so ubiquitous. As of 2002, over 1000 companies included mandatory binding arbitration in routine sales transactions."); Alexander A. Reinert, The Burdens of Pleading, 162 U. PA. L. REV. 1767, 1777 (2014) ("As the enforceability and scope of arbitration agreements have increased, arbitration has become ubiquitous across disparate areas of the law."); Judith Resnik, Comment, Fairness in Numbers: A Comment on AT\&T v. Concepcion, Wal-Mart v. Dukes, and Turner v. Rogers, 125 HARV. L. REV. 78, 121-22 (2011). But cf. Peter B. Rutledge \& Christopher R. Drahozal, "Sticky" Arbitration Clauses?: The Use of Arbitration Clauses After Conception and Amex, 67 VAND. L. REV. 
make antitrust claims less lucrative and harder to bring. For example, some arbitration clauses attempt to preclude antitrust plaintiffs from recovering the treble damages mandated by federal antitrust law. So far, courts have rejected such attempts. ${ }^{52}$ Courts have, however, been more amenable to defendants' attempts to use arbitration clauses in order to shorten the Clayton Act's four-year statute of limitations $^{53}$ and to eliminate the antitrust provision that allows a successful plaintiff to recover attorneys' fees. ${ }^{54}$

Most controversially, many arbitration clauses prohibit class action litigation. ${ }^{55}$ While these class action waivers have been widely criticized by scholars, judges, and legislators, ${ }^{56}$ the Supreme Court has been decidedly less wary. When, for example, the California Supreme Court condemned class action waivers in consumer contracts as unconscionable, ${ }^{57}$ the U.S. Supreme Court, in AT\&T Mobility LLC v. Concepcion, reversed the California rule. ${ }^{58}$ The Court reasoned that the FAA preempted state attempts to invalidate class action waivers contained in arbitration clauses. ${ }^{59}$ Although Concepcion involved state-based consumer law, the decision seemed to endorse class action waivers more broadly. ${ }^{60}$

In addition to making it more difficult for antitrust plaintiffs to bring class action litigation in federal court, the Supreme Court, in Stolt-Nielsen S.A. $v$. AnimalFeeds International Corp., also made it easier for antitrust defendants to evade class-wide arbitration. ${ }^{61}$ Because arbitration clauses now routinely prohibit

955 (2014) (finding that companies have been slower to adopt arbitration clauses in franchise contracts than others have predicted).

52. Kristian v. Comcast Corp., 446 F.3d 25, 29 (1st Cir. 2006).

53. In re Cotton Yarn Antitrust Litig., 505 F.3d at 288-89.

54. See, e.g., James C. Justice Cos., Inc. v. Deere \& Co., No. 5:06-cv-00287, 2008 WL 828923, at *5 (S.D. W. Va. Mar. 27, 2008) (The plaintiff "has offered no evidence that paying its own attorney's fees and costs in arbitration would prevent it from effectively vindicating its rights under the Sherman Act. Therefore, Court cannot conclude that the Dealership Agreement's limitation on attorney's fees and costs is inconsistent with the policies of the Sherman Act."); cf. Kristian, 446 F.3d at 52-53 (striking the anti-fee provision in an arbitration clause because "the ban on the recovery of attorney's fees and costs in the arbitration agreements would burden Plaintiffs here with prohibitive arbitration costs, preventing Plaintiffs from vindicating their statutory rights in arbitration").

55. See Homa, 494 F. App'x at 197 ("In the years since Congress adopted the FAA, clauses containing class-arbitration waivers have become ubiquitous in contracts involving products and services distributed or supplied on a mass basis, such as contracts providing for cell phone service, credit cards, and cable service.").

56. See, e.g., Davis v. Chase Bank USA, N.A., 299 F. App’x 662, 664 (9th Cir. 2008) (“[T]he class action waiver provision is both procedurally and substantively unconscionable."); Myriam Gilles \& Gary Friedman, After Class: Aggregate Litigation in the Wake of AT\&T Mobility v Concepcion, 79 U. CHI. L. REV. 623, 640-52 (2012).

57. See Discover Bank v. Superior Court of L.A., 113 P.3d 1100, 1108 (Cal. 2005).

58. AT\&T Mobility LLC v. Concepcion, 131 S. Ct. 1740, 1753 (2011).

59. Id.

60. Jean R. Sternlight, Tsunami: AT\&T Mobility LLC v. Concepcion Impedes Access to Justice, 90 OR. L. REv. 703, 718 (2012) ("In the near future, we can expect that even more companies will impose arbitral class action waivers as a means to insulate themselves from class actions because Concepcion has changed the calculus.").

61. Stolt-Nielsen S.A. v. AnimalFeeds Int'l Corp., 559 U.S. 662, 686 (2010). 
both class actions and class arbitration, victims of antitrust violations are often prevented from bringing any collective action. Indeed, some arbitration clauses prevented antitrust plaintiffs from coordinating in any fashion, including sharing the costs of developing common factual and economic data. ${ }^{62}$

After Concepcion and Stolt-Nielsen, however, antitrust plaintiffs still had another argument against class-action waivers in arbitration agreements: the Effective Vindication Doctrine. In making antitrust claims arbitrable, the Mitsubishi Court concluded that "so long as the prospective litigant effectively may vindicate its statutory cause of action in the arbitral forum, the statute will continue to serve both its remedial and deterrent function." 63 This language embodies the Effective Vindication Doctrine, which provides that "arbitration of the claim will not be compelled if the prospective litigant cannot effectively vindicate his statutory rights in the arbitral forum." ${ }^{64}$ The doctrine was designed to protect the statutory rights of antitrust victims. For example, courts have invoked the Effective Vindication Doctrine to invalidate the detrebling provisions embedded in arbitration clauses. ${ }^{65}$

In 2012, the Second Circuit applied the Effective Vindication Doctrine to arbitration clauses that forbid class action litigation and classwide arbitration. In In re American Express Merchants' Litigation, a group of merchants entered into contracts with American Express that contained arbitration clauses, which provided that "[t]here shall be no right or authority for any Claims to be arbitrated on a class action basis...."66 Despite signing these class action waivers, the merchants filed an antitrust class action in federal court. The merchants argued that because the necessary expert witnesses were so expensive, and because there was so little money at stake for any one merchant, compelling the merchants to individually arbitrate would prevent them from effectively vindicating their rights to an antitrust remedy; a class action represented the only cost-effective form of adjudication. After the district court granted American Express' motion to dismiss based on the arbitration clause, the Second Circuit reversed, holding that "the plaintiffs have adequately demonstrated that the class action waiver provision at issue should not be enforced because enforcement of the clause would effectively

62. See, e.g., Am. Express Co. v. Italian Colors Rest., 133 S. Ct. 2304, 2316 (2013) (Kagan, J., dissenting) ("[The arbitration agreement's] confidentiality provision prevents Italian Colors from informally arranging with other merchants to produce a common expert report.... In short, the agreement as applied in this case cuts off not just class arbitration, but any avenue for sharing, shifting, or shrinking necessary costs.").

63. Mitsubishi Motors Corp. v. Soler Chrysler-Plymouth, Inc., 473 U.S. 614, 637 (1985).

64. In re Cotton Yarn Antitrust Litig., 505 F.3d 274, 282-83 (4th Cir. 2007) (citing Green Tree Fin. Corp.-Ala. v. Randolph, 531 U.S. 79, 90 (2000)); see also Am. Express Co., 133 S. Ct. at 2314 (Kagan, J., dissenting) ("[The Effective Vindication Doctrine provides that a]n arbitration clause will not be enforced if it prevents the effective vindication of federal statutory rights, however it achieves that result.").

65. Kristian v. Comcast Corp., 446 F.3d 25, 37, 47-48 (1st Cir. 2006) (invoking Mitsubishi to disapprove such waivers).

66. In re Am. Express Merchants' Litig., 667 F.3d 204, 209 (2d Cir. 2012). 
preclude any action seeking to vindicate the statutory rights asserted by the plaintiffs." ${ }^{67}$ The Supreme Court vacated the Second Circuit decision in light of its opinion in Concepcion, which held that the FAA preempted California's rule against class arbitration waivers in consumer contracts. ${ }^{68}$ On remand, the Second Circuit again held that the Effective Vindication Doctrine precluded mandatory individual arbitration of the merchants' claims.

In American Express Co. v. Italian Colors Restaurant, the Supreme Court again considered whether the Effective Vindication Doctrine excused the merchants from the mandatory arbitration clause. ${ }^{69}$ Writing for the majority, Justice Scalia applied the doctrine to the facts of Italian Colors. He noted the merchants' evidence "from an economist who estimated that the cost of an expert analysis necessary to prove the antitrust claims would be 'at least several hundred thousand dollars, and might exceed $\$ 1$ million,' while the maximum recovery for an individual plaintiff would be $\$ 12,850$, or $\$ 38,549$ when trebled."70 Scalia asserted that what mattered was the right to pursue an antitrust remedy, not whether the merchants could exercise that right economically; he proclaimed that "the fact that it is not worth the expense involved in proving a statutory remedy does not constitute the elimination of the right to pursue that remedy." "71 As applied, this meant "a contractual waiver of class arbitration is enforceable under the Federal Arbitration Act when the plaintiff's cost of individually arbitrating a federal statutory claim exceeds the potential recovery." 72 Consequently, the Court held that potential defendants can use arbitration clauses to prevent class actions, even when a class action is the only way to effectively vindicate the right to an antitrust remedy. ${ }^{73}$ According to Justice Scalia, "the antitrust laws do not guarantee an affordable procedural path to the vindication of every claim."74

In the aftermath of Italian Colors, potential antitrust defendants have every incentive to include class action waivers in their mandatory arbitration clauses. ${ }^{75}$

67. In re Am. Express Merchants' Litig., 554 F.3d 300, 304 (2d Cir. 2009), cert. granted, judgment vacated sub nom. Am. Express Co. v. Italian Colors Rest., 130 S. Ct. 2401 (2010) (Mem).

68. AT\&T Mobility LLC v. Concepcion, 131 S. Ct. 1740, 1753 (2011). Although Concepcion seemed to reject the effective vindication doctrine in context of state claims, the case "was decided on preemption grounds ... and the Supreme Court had no occasion in that case to decide whether access to class proceedings was necessary for the effective vindication of a federal statutory right." Ellen Meriwether, Class Action Waiver and the Effective Vindication Doctrine at the Antitrust/Arbitration Crossroads, 26 Antitrust 67, 67 (2012); cf. Am. Express Co. v. Italian Colors Rest., 133 S. Ct. 2304, 2319-20 (2013) (Kagan, J., dissenting) (“AT\&T Mobility was not—and could not have been —about the effective-vindication rule.").

69. Am. Express Co., 133 S. Ct. at 2307.

70. Id. at 2308 (citation omitted).

71. Id. at 2311.

72. See id. at 2307.

73. Id. at 2311 (discussing Gilmer v. Interstate/Johnson Lane Corp., 500 U.S. 20, 32 (1991)).

74. Id. at 2309 .

75. See, e.g., Einer Elhauge, How Italian Colors Guts Private Antitrust Enforcement By Replacing It With Ineffective Forms of Arbitration 8 (Working Paper, 2015) (on file with authors) 
And they are increasingly doing so - the number of large companies that include such waivers has more than doubled since Conception and Italian Colors ${ }^{76}$ The proliferation of arbitration clauses, combined with class action waivers, fundamentally changes the legal environment from the one that existed during the mid-1970s when the Court decided Illinois Brick. The Illinois Brick majority assumed that antitrust claims would be litigated, not arbitrated, and that they could be litigated as class actions.

\section{ITALIAN COLORS UNDERMINES THE RATIONALE OF ILLINOIS BRICK}

Illinois Brick was based on two central premises. First, the Court assumed that direct purchasers were the best private antitrust plaintiffs. ${ }^{77}$ Unlike competitors, purchasers have incentives that are generally aligned with the public interest in a competitive market. And among purchasers, the Court reasoned that direct purchasers have more concentrated interests than ultimate consumers, so they may be more likely to sue - and to hire better lawyers when they do. The calculation of damages is also simpler when only one transaction has occurred than when courts have to trace the pass-through of the overcharge. ${ }^{78}$

Second, the Illinois Brick Court worried about the risk of double compensation if it permitted indirect purchasers to sue as well as direct purchasers. In Hanover Shoe, Inc. v. United Shoe Machinery Corp., a 1968 case, the Court held that an antitrust defendant could not claim a deduction for a price overcharge that the direct purchaser passed through to downstream purchasers. ${ }^{79}$ Because of that decision, nine years later in Illinois Brick, the Court worried that allowing both the direct and the downstream purchaser to sue would result in a double recovery ${ }^{80}$ While antitrust law does not always object to multiple recoveries - the Clayton Act awards treble damages in order to deter undetected antitrust violations ${ }^{81}$ - the

("Given the Italian Colors decision, it is hard to see why all businesses would not at least insert arbitration clauses into their contracts that preclude class arbitration.").

76. See, e.g., Jeremy B. Merrill, One-Third of Top Websites Restrict Customers' Right to Sue, N.Y. Times (Oct. 23, 2014), http://www.nytimes.com/2014/10/23/upshot/one-third-of-top-websitesrestrict-customers-right-to-sue.html?_r=0\&abt=0002\&abg=1 (noting that one-third of customer-facing web sites ban class actions by a "browsewrap" contract and that the number of contracts that ban class actions across all companies has "more than doubled" since the Court made them legal). For instances of courts applying arbitration to bar class antitrust claims, see, for example, In re Polyurethane Foam Antitrust Litig., 2014 WL 5365448 (N.D. Ohio Aug. 12, 2014) ("reluctantly" granting motion to compel arbitration because of Italian Colors); Paduano v. Express Scripts, 2014 WL 54313210 (E.D.N.Y. Oct. 27 , 2014) (granting motion to compel arbitration under an agreement that banned antitrust class arbitrations).

77. See supra notes $15-18$ and accompanying text.

78. Cf. Clayworth v. Pfizer, Inc., 49 Cal. 4th 758 (2010) (refusing to allow defendants to assert a pass-through defense).

79. Hanover Shoe, Inc. v. United Shoe Mach. Corp., 392 U.S. 481, 494 (1968).

80. Ill. Brick Co. v. Illinois, 431 U.S. 720, 730 (1977).

81. 15 U.S.C. $§ 15 a(2013)$; see also Joshua P. Davis \& Robert H. Lande, Toward an Empirical and Theoretical Assessment of Private Antitrust Enforcement, 36 SEATtLE U. L. REV. 1269 (2013); $c$. Christopher R. Leslie, De Facto Detrebling: The Rush to Settlement in Antitrust Class Action Litigation, 
Court was clearly concerned by the prospect that the defendant would have to pay damages from the same sale to two or more plaintiffs. ${ }^{82}$

Both pillars of the Illinois Brick argument collapse after Italian Colors. As antitrust arbitration agreements become more common in sales contracts, many direct purchasers are no longer able to file antitrust suits challenging overcharges. They can theoretically arbitrate those disputes, but in doing so they will not necessarily get the advantages antitrust law consciously offers to induce suit: treble damages and attorneys' fees. ${ }^{83}$ In addition, because arbitration proceedings are almost always confidential, ${ }^{84}$ the world will not benefit from learning about the antitrust violation and subsequent plaintiffs will not benefit from collateral estoppel. ${ }^{85}$

Further, because the Supreme Court has allowed arbitration agreements to forbid class actions, ${ }^{86}$ antitrust enforcement will be particularly ineffective in circumstances in which the direct purchases involve a large group of small-value transactions. The named plaintiff in Italian Colors, for instance, had only a small amount personally at stake. ${ }^{87} \mathrm{~A}$ class of such plaintiffs may well have an incentive to sue, but individuals certainly will not arbitrate when the expected costs of arbitration exceed the maximum individual recovery. Even if the individual had the desire, no rational attorney would take the case.

The use of arbitration clauses to impede class action litigation is particularly disruptive in the context of antitrust violations, which often impose relatively low costs on a relatively large group of victims. This is precisely the scenario for which class actions were designed. Consequently, federal judges have noted that "the Supreme Court has long recognized that class actions serve a valuable role in the enforcement of antitrust laws." ${ }^{88}$ In particular, retailer class actions- such as the

50 ARIZ. L. REV. 1009, 1009-10 (2008) (explaining how courts interfere with the treble damages regime).

82. Ill. Brick Co., 431 U.S. at 730-31.

83. Kristian v. Comcast Corp., 446 F.3d 25, 47-48 (1st Cir. 2006), held that restrictions on treble damages in antitrust arbitration agreements were unenforceable. But it is not clear that that ruling will survive American Express Co. v. Italian Colors Restaurant, 133 S. Ct. 2304, 2309-11 (2013).

84. See, e.g., Global Reinsurance Corp.-U.S. Branch v. Argonaut Ins. Co., Nos. 07 Civ. 8196(PKC), 07 Civ. 8350(PKC), 2008 WL 1805459, at*1 (S.D.N.Y. Apr. 21, 2008) ("The federal policy in favor of arbitration is promoted by permitting one of the principle [sic] advantages of arbitration—confidentiality—-to be achieved.").

85. Arbitration normally does not create precedent that binds the participants in subsequent litigation with non-parties. See, e.g., Vandenberg v. Superior Court, 982 P.2d 229 (Cal. 1999). But some courts have applied collateral estoppel to antitrust arbitrations. See Global Live Events v. Ja-Tail Enters., LLC, No. CV 13-8293 SVW, 2014 WL 1830998, at *3 (C.D. Cal. May 8, 2014).

86. AT\&T Mobility LLC v. Concepcion, 131 S. Ct. 1740, 1750-53 (2011) (holding that classes are not permitted to arbitrate antitrust disputes because class action procedure interferes with the operation of arbitration). Italian Colors extended that conclusion even to cases when it was clear that it was infeasible to bring a case except as a class action.

87. Italian Colors Rest., 133 S. Ct. at 2316 (Kagan, J., dissenting) (noting that at most Italian Colors could have recovered less than $\$ 40,000$, far less than it costs to litigate a rule of reason antitrust case).

88. In re High-Tech Emp. Antitrust Litig., 985 F. Supp. 2d 1167, 1179 (N.D. Cal. 2013). 
one that Italian Colors put an effective end to-have been historically important. ${ }^{89}$ Because of the proliferation of arbitration clauses, direct purchasers in a postItalian Colors world are no longer the most obvious plaintiffs. If direct purchasers are effectively prevented from securing full compensation for the antitrust injuries, the possibility of damages being passed on to indirect purchasers is eliminated. In the aftermath of Italian Colors, indirect purchasers may be in a better position to hold antitrust violators accountable because they are less likely to be bound by an arbitration clause, which requires consent. ${ }^{90}$ Consequently, a class of indirect purchasers is likely to be a better antitrust plaintiff than an individual direct purchaser forced to arbitrate her antitrust dispute. This undermines one of the key assumptions upon which Illinois Brick is based.

Because direct purchasers are less likely to bring claims after Italian Colors, the Illinois Brick Court's worry about double compensation is also substantially reduced. If a direct purchaser is subject to an arbitration agreement and is unlikely to bring a claim, there is little risk of double compensation. Moreover, excessive compensation is particularly unlikely in the context of class actions because successful participants in antitrust class actions generally receive "less than single damages." 91 Thus, even if direct purchasers and indirect purchasers were to bring parallel class actions for the same antitrust violation, the losing defendant is likely to pay out less than the treble damages mandated by antitrust law. Further, the calculation of injury may be substantially simpler in cases in which the direct purchaser cannot practically sue and therefore overcharges need not be apportioned. Consequently, the more serious risk in this new antitrust world is undercompensation and underdeterrence.

89. See, e.g., Lloyd Constantine, Priceless: The Case That Brought Down the VISA/MASTERCARD BANK CARTEL (2013).

90. Stolt-Nielsen S.A. v. AnimalFeeds Int'l Corp., 559 U.S. 662, 681 (2010) (“[T]he FAA imposes certain rules of fundamental importance, including the basic precept that arbitration 'is a matter of consent, not coercion.”' (quoting Volt Info. Scis., Inc. v. Bd. of Trs. of Leland Stanford Junior Univ., 489 U.S. 468,479 (1989))). In a world in which courts seem to enforce anything one party labels as a contract, whether or not it is signed or even visible to the "agreeing" party, see generally NANCY S. Kim, Wrap Contracts (2013); Mark A. Lemley, Terms of Use, 91 MinN. L. REV. 459 (2006), there is some risk that even indirect purchasers in some industries like software will be bound to these arbitration agreements as well. That is a limitation on our proposal. But it will not make it completely ineffective. And we think the right solution is for courts to impose some reasonable limits on the ability to compel arbitration through such form contracts, as some courts have done. For an example of an electronic arbitration clause found unconscionable, see Comb v. PayPal, Inc., 218 F. Supp. 2d 1165, 1177 (N.D. Cal. 2002); Briceño v. Sprint Spectrum, L.P., 911 So. 2d 176, 178 (Fla. Dist. Ct. App. 2005). But see Hubbert v. Dell Corp., 835 N.E.2d 113, 117-19 (Ill. App. Ct. 2005) (enforcing an arbitration clause included in an online "Terms and Conditions of Sale" hyperlink). One study showed that courts found arbitration clauses unconscionable at twice the rate they found other provisions unconscionable. Susan Randall, Judicial Attitudes Toward Arbitration and the Resurgence of Unconscionability, 52 BUFF. L. REV. 185, 186 (2004).

91. See John M. Connor, Price-Fixing Overcharges: Revised 3rd Edition 1 (Am. Antitrust Inst., 2014), available at http://papers.ssrn.com/sol3/papers.cfm?abstract_id $=2400780$ (finding after exhaustive study that "[h]istorical penalty guidelines aimed at optimally deterring cartels are likely to be too low"); Leslie, supra note 80, at 1040. 
In short, at least based on the Court's stated rationale, Illinois Brick would have come out the other way in today's world-a world in which antitrust arbitration agreements with direct purchasers are increasingly common and class actions by direct purchasers correspondingly more difficult.

\section{IMPLICATIONS FOR ANTITRUST LAW}

In the 1970s, antitrust scholars worried that there was too much antitrust enforcement. ${ }^{92}$ Illinois Brick and the antitrust injury doctrine were judicial responses to that worry. While other decisions limited the substantive reach of antitrust law, those cases limited the circumstances under which private parties could enforce that substantive law.

The world has changed. In a series of cases over the past three decades, the Supreme Court has dramatically reduced the substantive reach of antitrust law. ${ }^{93}$ Government enforcement has also declined. ${ }^{94}$ And Italian Colors is likely to make private enforcement infeasible for the single best class of private plaintiffs: direct purchasers.

In the wake of Italian Colors, the more reasonable worry is that antitrust violations will go unremedied because the best plaintiff is likely to be foreclosed from enforcing the law by a standard-form contract. And if direct purchasers are unavailable as plaintiffs, indirect purchasers will often be a better substitute than competitors. Italian Colors and Illinois Brick together operate to preclude even indisputably valid antitrust claims; the latter eliminates indirect purchasers as plaintiffs, while the former hampers the ability of direct purchasers to sue. In short, leaving politics aside, had the Court that wrote Illinois Brick confronted the facts of antitrust as it now exists, it would have come to a very different conclusion about the suitability of indirect purchasers as plaintiffs.

The solution is correspondingly simple: Illinois Brick should be overruled. It is based on a set of judgments about antitrust law that are obsolete. If the Supreme Court is unwilling to overrule Illinois Brick, Congress and the remaining state

92. See, e.g., Frank H. Easterbrook, The Limits of Antitrust, 63 TEX. L. REV. 1, 3 (1984).

93. See, e.g., Stacey L. Dogan \& Mark A. Lemley, Antitrust Law and Regulatory Gaming, 87 TEX. L. Rev. 685, 700-01 (2009).

Judge Easterbrook could speak in 1984 of the asymmetry between false positives and false negatives, but the antitrust law he was talking about simply doesn't exist anymore. Courts in the last three decades have dismantled every per se rule applied to vertical conduct, limited the per se rule in horizontal conspiracies in a variety of ways, made it harder for plaintiffs to infer conspiracies, all but eliminated predatory-pricing claims, and substantially restricted the role of monopolization cases. Win rates for antitrust plaintiffs in at least one industry hover below $15 \%$, and court rules make it harder and harder for antitrust plaintiffs to show standing to sue to enforce the laws that remain.

Id. (footnotes omitted). We have no doubt that antitrust at one time was skewed toward overenforcement, but today if there is any bias it is in the opposite direction.

94. Id. at $702 \mathrm{n} .78$ ("[T]he Antitrust Division has filed pro-defendant briefs in all of the major antitrust cases before the Supreme Court in the past five years."). While that was true in 2009, the change in administration brought with it a somewhat more aggressive approach. 
legislatures should repeal the doctrine, allowing suits by indirect purchasers. Alternatively, the Court could limit the reach of Illinois Brick to circumstances in which direct purchasers either have already filed suit or, at the very least, are permitted to do so. Repealing Illinois Brick only in the subset of cases in which the defendants actually compelled arbitration would most fully avoid the double compensation problem the Court identified. It would also help discourage the widespread use of antitrust arbitration agreements. ${ }^{95}$

We acknowledge that shifting antitrust enforcement to indirect purchasers is a second-best solution ${ }^{96}$ because tracing the effect of the overcharge to indirect purchasers is harder than simply measuring the price charged to direct purchasers. ${ }^{97}$ Still, Italian Colors may have broader implications for antitrust standing. If the best plaintiffs are no longer available, we might permit standing not only by indirect purchasers, but also by competitors under circumstances in which we currently do not.

We think the Italian Colors decision was probably a mistake and the best solution would be to overrule it. But since it is unlikely the Supreme Court will reverse a decision it made only one year ago, ${ }^{98}$ we proceed on the assumption that Italian Colors will remain the law. And if it does, repealing or limiting Illinois Brick will go a long way toward mitigating the harm it caused.

95. For other ways to limit the effects of Italian Colors, see Mark A. Lemley \& Christopher R. Leslie, Antitrust Arbitration and Merger Approval, __ Nw. U. L. REV. _, draft at 38-43 (forthcoming 2015).

96. See Christopher R. Leslie, Achieving Efficiency Through Collusion: A Market Failure Defense to Horizontal Price-Fixing, 81 CALIF. L. REV. 243, 267-69 (1993) (discussing the theory of the second best).

97. Furthermore, a class action brought by indirect purchasers will necessarily have significantly more class members than a class action brought by direct purchasers, which can increase the agency costs associated with class action litigation.

98. It is possible that Congress will reverse Italian Colors, but it seems unlikely. Congress has traditionally been very pro-arbitration, and indeed the Federal Arbitration Act has been interpreted as a deliberate effort by Congress to strengthen arbitration over judicial opposition. Am. Express Co. v. Italian Colors Rest., 133 S. Ct. 2304, 2309 (2013). Efforts to pass the proposed Arbitration Fairness Act, which would limit the ability of companies to impose mandatory arbitration clauses on consumers and expressly overrule Italian Colors, have so far failed. See generally Martin H. Malin, The Arbitration Fairness Act: It Need Not and Should Not Be an All or Nothing Proposition, 87 IND. L.J. 289 (2012) (advocating for reform at least as extensive as the AFA). 